\title{
ARTICLE \\ Lives From Death Row: Common Sinners and Current Pasts
}

\author{
Ben Moats \\ The University of Miami and Exchange for Change, US \\ Bxm526@miami.edu
}

This analysis interrogates Mumia Abu-Jamal's Live From Death Row to argue that unlike traditional personal narratives or memoirs, the diverse series of vignettes in Abu-Jamal's most famous publication provoke readers to grapple not solely with his lived experiences on death row or the lived experiences of his fellow inmates; they also call for readers to confront the damming moral, social, and economic impact of mass incarceration on society at large. His internal account of prison life, therefore, depicts the inmates of Pennsylvania's Huntingdon County prison not as moral aliens but as human beings and what early New England execution sermons describe as "common sinners." More specifically, Abu-Jamal's arguments linking the "free" with the condemned work on two basic levels. First and foremost, they illuminate the ways we all share a common history of racism by implicitly revealing the connections between slavery, Dred Scott, Plessey v. Ferguson, Jim Crow, the civil rights movement, McCleskey v. Kemp, and the ideological prejudices that still permeate and influence our legal, political, and social systems today. Thus, given Abu-Jamal's compassionate internal account of prison life; his analysis of the all-to-frequent harsh realities of our justice system; as well as his common-sense plea for reform, this analysis contends that Live From Death Row continues to speak with more contemporary works like Michelle Alexander's The New Jim Crow, Netflix's 13 ${ }^{\text {th }}$, Angela Y. Davis' Are Prisons Obsolete?, and Abolition Now!. Numbers have changed; policies have evolved; voices of opposition have heightened; yet the lockup continues, making Abu-Jamal's cry for reform and humanity as essential as ever.

Keywords: mass incarceration; race; death row; common sinners; prison life; prison-industrial complex; common humanity; prison reform; prison narrative; criminal justice reform; the Baldus study; McCleskey v. Kemp; history of the present

Mumia Abu-Jamal, perhaps the most famous person living on death row until his death sentence was vacated in 2011, exercises his Fifth-Amendment right by refusing to provide a full disclosure of his account of the events that took place on that Philadelphia corner of Thirteenth and Locust in the early morning hours of December $9^{\text {th }}$, 1981. In 2001, Abu-Jamal did sign a statement professing his innocence, but aside from the sparse details provided in this brief document, ${ }^{1}$ he has been largely mute regarding the particularities of his life-altering encounter with Officer Faulkner. What is undisputed, however, is that on that winter morning, shortly after 4:00 am, Abu-Jamal was found gravely injured at the aforementioned location, lying in very close proximity to a fatally wounded police officer, Daniel Faulkner, with a .38-Mumia's .38-holding five empty rounds and resting upon the bloody pavement between the two.

Regardless of Abu-Jamal's guilt or innocence, the trial that followed was undoubtedly a biased, judicial folly on multiple fronts. Like Live From Death Row, however, the focus of this analysis will not be on those issues. Certainly, a clear revelation of Abu-Jamal's guilt or innocence in the court of public opinion would undoubtedly alter the readings and perceptions of his most famous publication for many. But an honest

\footnotetext{
${ }^{1}$ Abu-Jamal, Mumia. "Declaration of Mumia Abu-Jamal." Free Mumia. www.freemumia.com/declaration-of-mumia-abu-jamal/. 26 Jan. 2018.
} 
verdict of "guilty" or "not guilty" would (or at least should) do very little, if anything, to alter or call into question the true strengths of his writing: most importantly, that unlike traditional personal narratives or memoirs, the diverse series of vignettes in Live From Death Row not only provoke readers to grapple with the lived experiences of one man's life on death row, Abu-Jamal's writing inhabits the lives of those living in confinement around him as well. Furthermore, this particular internal account of prison life depicts the inmates of Pennsylvania's Huntingdon County prison not as moral aliens but as human beings, what early New England execution sermons describe as "common sinners."

Given the ongoing, inhumane, and unsustainable growth of the US prison industrial complex, Live From Death Row's "common sinner" call for reform continues to be both an imperative reaction to the realities of today as well as an implicit explication of how contemporary currents are shaped by our shared history. In this way, Abu-Jamal's writing is as relevant now as when it was first published over twenty years ago. In the late 1960s, Angela Y. Davis writes of being "astounded to learn that there were then close to two hundred thousand people in prison" (11). By 1981, the US ranked only behind Russia and South Africa in the percentage of its population living behind bars (Wideman xxvi). When Live From Death Row was published in 1995, however, the US had taken over the number one spot with over 1.5 million of its citizens living behind bars, amounting to approximately 592 prisoners per 100,000 people. ${ }^{3}$ By 2013, it housed over 2.2 million prisoners with 693 per 100,000, ${ }^{4}$ and today, while the total prison population has dropped slightly, over 2 million US citizens remain behind bars. Thus, given his compassionate internal account of prison life; his analysis of the all-to-frequent harsh realities of our justice system; as well as his common-sense plea for reform, Live From Death Row continues to speak with more contemporary works like Michelle Alexander's The New Jim Crow, Netflix's $13^{\text {th }}$, Angela Y. Davis' Are Prisons Obsolete?, and Abolition Now!. Numbers have changed; policies have evolved; voices of opposition have heightened; yet the lockup continues: making Abu-Jamal's cry for reform and humanity as essential as ever.

Brian Conniff and John Edgar Wideman provide useful, brief explorations of how Live From Death Row is unique not only in its humanizing depiction of prisoners but also in its form, structure, and epistemology. Conniff notes, for example, how the work views those living behind bars as "shar[ing] in a common humanity" (170), while John Edgar Wideman argues that Abu-Jamal's writing decidedly differs from the neoslave narrative, a narrative he defines as "the countless up-from-the-depths biographies and autobiographies of black people that repeat the form and assumptions of the slave narrative" (xxix). The neoslave narrative, Wideman claims, "sells because it is simple; because it accepts and maintains the categories (black/white, for instance) of the status quo; because it is about individuals, not groups, crossing boundaries..." (xxx). In other words, although many US citizens happily embrace stories about one man or one woman overcoming insurmountable odds to obtain freedom, wealth, equality, justice, etc., much less frequently do we rejoice over works that question-rather than reaffirm-current political, social, or belief systems by calling to action an entire race, gender, movement, or nation. Somehow the tale of one African American overcoming poverty and family strife to obtain massive wealth and presumed contentment (i.e. The Pursuit of Happiness) seems much more palatable to the American psyche than does any work that rebuffs these kinds of narratives that are the lifeblood of "The American Dream": a dream Live From Death Row unabashedly refuses to reinforce. Just as Abu-Jamal rejects these isolated rags-to-riches stories put forth in many of our films, novels, and textbooks, there is also no dualism in his writing. As Wideman notes, "He doesn't split his world down the middle to conform to the divided world prison enforces. He expresses the necessity of connection, relinquishing to no person or group the power to define him" (xxxii).

What is more briefly touched upon in Wideman's introduction and Conniff's essay, however, is more deeply explored and analyzed in this work: namely, how Live From Death Row stands as a testimony of one whose writing questions and condemns the prison-industrial complex as well as contemporary perceptions of inmates by showing the ways in which the "free" and the "non-free" are connected as human beings and "common sinners." More specifically, Abu-Jamal's arguments linking the "free" with the condemned work

\footnotetext{
${ }^{2}$ As will be explored, author Karen Halttunen describes the early New England perception of murderers and criminals to be much more sympathetic than our contemporary views regarding prisoners. Integrating the words, spoken in 1733, of Rev. Thomas Foxcroft, for example, Halttunen writes, "The only difference between the condemned murderer and the rest of humanity was 'the restraining grace of God, to whose name alone belongs the Praise, that any of us have been with-held from the grossest and most horrid Acts of Wickedness'" (15).

3 The World Prison Brief. www.prisonstudies.org/. 26 Jan. 2018.

${ }^{4}$ Glaze, Lauren E. and Danielle Kaeble. "Correctional Populations in the United States, 2013." Bureau of Justice Statistics. www.bjs. gov/index.cfm?ty=pbdetail\&iid=5177.
} 
on two basic levels. First and foremost, they illuminate the ways we all share a common history of racism by implicitly revealing the connections between slavery, Dred Scott, Plessey v. Ferguson, Jim Crow, the civil rights movement, McCleskey v. Kemp, and the ideological prejudices that still permeate and influence our legal, political, and social systems today.

Secondly, even for readers who will not accept the premise that prisoners and non-prisoners share a common humanity by way of their common history, Abu-Jamal's writing more explicitly reveals the intricate connections that exist between the "free" and the condemned by showing how we are all conjoined in economic, educational, psychological, and sometimes even physical ways. Hence, although Live From Death Row can speak to readers both willing and unwilling to accept the humanity of those living behind bars, the author of Live From Death Row makes no such concessions. In the eyes of Abu-Jamal, the men and women living within our prison systems are not moral monsters but products of our shared history and therefore "common sinners": a perception that, oddly enough, is much more akin to early New England execution sermons than contemporary attitudes regarding the incarcerated.

\section{Death Row Inmate As "Common Sinner"}

In Murder Most Foul, Karen Haltunnen contrasts her perception of the early New England execution ritual with Michel Foucault's understanding of public executions in early modern Europe. In Foucault's view, Halttunen writes, "public execution was a ceremony designed to 'inscribe' the power of the state on the suffering body of the individual, and thus publicize the advisability of obedience" (22). In New England's public executions, on the other hand, rather than depicting the capital criminal as an isolated social anomaly, preachers like Cotton Mather lamented that "even husbands who spoke harshly to their wives were guilty of murder" (15). Halttunen therefore notes that "[n]o one, it appeared, was innocent of the crime" (15), and thus proceeds to claim that in "early New England, the 'theater of punishment' was actually a 'Theater of Mercy,' demonstrating the path to salvation for all sinners" (23). ${ }^{5}$

This certainly does not mean these early New England preachers were truly merciful religious leaders on all levels, and many likely possessed a strong desire to discipline and punish in their own way. However, in a similar fashion as Halttuen, Daniel A. Cohen writes of the Puritan's "common sinner" mindset, noting that "They believed their own community stood in a special, covenantal relationship with God in which they would be held collectively responsible for the wrongdoing of individual members" (7). Yet Cohen also points out the darker side of this belief system when he writes, "... they believed that all men and women were naturally prone to wickedness..." (7), a perception that Live From Death Row simply does not embrace. Despite these concessions, the Puritan communities did view even those who committed the most heinous crimes not as moral monsters but as "common sinners," sinners who, because their execution date was fast approaching, were in dire need of a pastor's guidance in order to exhibit true repentance. Live From Death Row works to reestablish that pre-eighteenth century perception of prisoners as human beings, intimately and intricately connected to the "free" men and women who live their lives outside of prison walls.

In some respects, Abu-Jamal is even like those early New England preachers presenting their execution sermons. Certainly, there are differences: he does not suggest that human beings are innately deprived; he does not present his arguments within a theological framework; he is vehemently opposed to the death penalty; and he does not claim to possess any theological form of moral authority. In Live From Death Row, however, Abu-Jamal does depict his fellow inmates in a manner similar to early New England execution sermons. Abu-Jamal's "sinners" are not linked with the outside community through Adam's original fall, but like many of the men and women living in early New England, all members of society are implicated in the act of crime and the process of punishment. Furthermore, Abu-Jamal's language is not one of exclusion; it does not depict the incarcerated in a manner that clearly demarcates them from the rest of society, nor does it strip these men and women of their humanity, regardless of their past crimes or current psychological states.

Harry Washington, for example, as depicted in "'On tilt' by state design," is a death-row inmate who has essentially gone insane: “... Harry, because of mind-snapping isolation, a bitterly racist environment, and the ironies, the auguries of fate, has begun the slide from depression, through deterioration, to dementia" (24). Brian Conniff explains nicely how Abu-Jamal's inclusive language when speaking of Washington forces the reader to view Harry as something most Americans would rather go on believing he is not-a human being:

\footnotetext{
${ }^{5}$ Stuart Banner, author of The Death Penalty, also echoes this sentiment when he writes, "Before the late eighteenth century Americans tended to understand criminals as people like themselves, human beings who had been overcome by the same tendency toward evil that afflicted everyone, so the criminals' penitence was an object of common concern" (22).
} 
It is never enough, for Abu-Jamal, merely to portray or "explain" [Harry's] degradation. He must also obliterate the distance his readers would like to maintain from the Harry Washingtons of the world. He does it most basically by directly associating himself-"Harry and I are among the growing numbers of Pennsylvanians on death row"-with the most marginalized of his death-row companions. He also does it by invoking, in the same phrase, the language of common citizenry: after all, even on death row, he and Harry are both "Pennsylvanians." And he does it by telling Harry's story (170).

Like the early New England execution sermons, Abu-Jamal describes his fellow inmates-along with himselfas products and symptoms of their environment: a social atmosphere that includes political and judicial corruption, poverty, violence, drug addiction, and a history of racism that produces reverberations still felt today. In this sense, prisoners in Live From Death Row are not depraved, social anomalies but human beings and "common sinners."

\section{The Presence of the Past}

In Discipline and Punish, Foucault notes that in his historical analysis of the French penal system he is not interested in writing "a history of the past in terms of the present"; rather, he is interested in "writing the history of the present" (31). TS Eliot puts forth a similar notion in "Tradition and the Individual Talent" when, speaking of the necessity of writers obtaining a "historical sense," he writes that one must live "in what is not merely the present, but the present moment of the past" (541). Although Abu-Jamal's writing and analytical approach differ significantly from that of the canonical works of Foucault and Eliot, his own perceptions and use of history in Live From Death Row reveal that he too clearly views and analyzes society's contemporary ailments through an intellectual framework akin to Foucault's "history of the present," what Eliot calls the "presence of the past." In many respects, he takes the following assertion of Eliot and pushes it forward not merely as advice for writers but as an essential view for all: "And he is not likely to know what is to be done unless he lives in what is not merely the present, but the present moment of the past; unless he is conscious, not of what is dead, but of what is already living" (541). History, in the eyes of Abu-Jamal, Foucault, and Eliot, is clearly a living entity influencing and guiding the here and now. To use the words of John Edgar Wideman again, Abu-Jamal "reminds us that to move clearly in the present, we must understand the burden of our past" (xxv).

In an attempt to better illuminate this burden, immediately within the opening sections of Live From Death Row Abu-Jamal carefully places his analysis of Dred Scott alongside that of the MOVE massacre; the Baldus study alongside the high percentage of African Americans living on death row; and the words of Justice Brennan alongside his own. He also integrates Delbert Tibbs, a former death-row inmate himself, who invokes slavery, the Civil War, Medgar Evers, Little Rock, and "Bombingham," which steer Abu-Jamal back to discussing the same issues that were at stake in Dred Scott over 150 years ago: the perceived value of black lives. This structural tactic of explicitly juxtaposing these various events, rulings, and voices, both past and present, works implicitly to reinforce the perception that the shared burden of our past is the most essential way that we are all "common sinners" still suffering from the transgressions of our common history. In this way, Live From Death Row implicitly argues that we are connected not merely in the present moment but in "the present moment of the past."

Abu-Jamal evokes this sense of historical immediacy right away in his preface, as he makes historical references with contemporary implications: "I remember a front page of the Black Panther newspaper, bearing the quote "A black man has no rights that a white man is bound to respect"' (xvi). The quote in question is from the Dred Scott ruling of 1857, but it is noteworthy that-even though it is this decision that he will go on to analyze in the preface-Abu-Jamal does not quote from the Dred Scott ruling directly. Instead, he invokes the past as living within a more present moment by pulling the line from a Black Panther newspaper. As Abu-Jamal explains, these are the words of U.S. Supreme Court chief justice Roger Taney writing for the majority opinion in Dred Scott: a ruling that unabashedly states that African Americans are not citizens and therefore are not protected under the constitution. Although Abu-Jamal does not explicitly refer to any connection between this historic ruling and contemporary society in this opening passage, the implications are clear. Within the same page of the Dred Scott reference, he proceeds to discuss the MOVE massacre of May 13, 1985, and on the following page he refers to his own case and his "shock" about his denied appeal: "I could understand intellectually that American courts are reservoirs of racist sentiment and have historically been hostile to black defendants, but a lifetime of propaganda about American 'justice' is hard to shrug off" (xvii). Yet he spends little time sorrowfully lamenting his particular situation or the problems within our legal system in general. Abu-Jamal does not dichotomize his world to discuss the ways in which isolated African Americans, prisoners, religious leaders, or politicians must address these issues alone. Rather, 
he implies that the problems of our history have helped to produce the ailments of today, and that these ailments are not issues for any one particular race or movement but for all. Of what he calls "a lifetime of propaganda about American 'justice,"' for example, Abu-Jamal writes:

As I said, it's hard to shrug off, but maybe we can do it together ... Perhaps we can shrug off and shred some of the dangerous myths laid on our minds like a second skin-such as the "right" to a fair and impartial jury of our peers ... the "right" to a fair trial, even ... For the powerless and the poor, [these "rights"] are chimeras that vanish once one reaches out to claim them as something real or substantial. Don't expect the media networks to tell you, for they can't, because of the incestuousness between the media and the government, and big business, which they both serve. I can. Even if I must do so from the valley of the shadow of death, I will (xvii-xviii Emphasis mine).

Although Abu-Jamal does not shy away from the fact that he is a death-row inmate, even within the opening pages of Live From Death Row he refuses to speak as an inferior outsider. To the contrary, even though walls, barbed-wire fences, and armed prison guards physically separate him from the rest of the world, intellectually, emotionally, and spiritually, he stands, speaks, writes and suffers among us; he places no un-passable walls between the past and the present or between the "free" and the non-free. Rather, his inclusive language rejects dualist thinking and contends that the common difficulties "we" face are injustices that "we" must address "together." Abu-Jamal also uses this inclusive language as a way of entering into a dialogue with the reader: "Don't expect the media to tell you ..." (emphasis mine), he writes. As one who lives in "the valley of the shadow of death," however, Abu-Jamal can and does speak to and challenge his readers in a manner that major media networks often simply will not. In this way, just as his writing does not depict prisoners as being separated from society at large, Live From Death Row's inclusive language also does not simply finger and isolate any single outside organization, politician, religious leader, or movement. Rather, it puts the burden of change and truth upon you, the reader.

The residues of Abu-Jamal's inclusive language regarding the contemporary problems stemming from our common history of racism do not disappear after his preface; they are intimately present in nearly every section of the rest of the work. In the first section of part one, "Teetering on the brink between life and death," he notes, "You will find a blacker world on death-row than anywhere else" (5). Certainly, Abu-Jamal does not suggest that the historical injustices faced by African Americans somehow fully absolve individuals from taking responsibility for their own actions today. As he notes, "Statistics are often flexible in interpretation and, like scripture, can be cited for any purpose. Does [the disproportionate percentage of blacks on death-row] mean that African-Americans are somehow innocents, subjected to a setup by state officials? Not especially" (76). Yet even with the problem of statistics noted, Abu-Jamal refers to the troubling findings of the Baldus study and the unfortunate ruling of the Supreme Court in McCleskey v. Kemp to show how ripples from our prejudiced past are still being felt today.

In 1978, Warren McCleskey was convicted of two counts of robbery and one count of murder in Fulton County, Georgia. McCleskey, a black man, was found guilty of the murder of a white police officer and was sentenced to death. In an attempt to overturn his death sentence, McCleskey's defense used a statistical study of Professors David C. Baldus, Charles Pulaski, and George Woodworth. The study "purports to show a disparity in the imposition of the death sentence in Georgia based on the race of the murder victim and, to a lesser extent, the race of the defendant" (Latzer 232). Most importantly, and as Abu-Jamal points out, the findings of the Baldus study-which considered murder cases in Georgia over a five-year period (19731978)-revealed that:

defendants charged with killing whites are 4.3 times more likely to be sentenced to die than defendants charged with killing blacks; six of every eleven defendants convicted of killing a white would not have received a death sentence had their victim been black... [T] here was a significant chance that race would play a prominent role in determining if [a defendant] lived or died (qtd. in Abu-Jamal 12).

Similarly, as was noted in the Court's opinion in McCleskey v. Kemp:

Baldus found that prosecutors sought the death penalty in 70 percent of the cases involving black defendants and white victims; 32 percent of the cases involving white defendants and white victims; 15 percent of the cases involving black defendants and black victims; and 19 percent of the cases involving white defendants and black victims (Latzer 233). 
McCleskey's appeal, however, was denied when it went to the Supreme Court, where it was defeated in a five to four vote. As Brian Conniff notes, what is most shocking to Abu-Jamal in the Court's opinion is not that it disputes the findings of the Baldus study (it does not), but that "it decides that the evidence does not matter" (163). Here, Abu-Jamal analyzes what the court's opinion in the McCleskey case considers (and fails to consider) to present his own arguments, arguments first cultivated in the isolation of a jail cell and then put forth to the court of public opinion.

One aspect of McCleskey v. Kemp that the court does not fail to note is that "McCleskey's claim of discrimination extends to every actor in the Georgia capital sentencing process, from the prosecutor who sought the death penalty and the jury that imposed the sentence, to the State itself ..." (Latzer 234). Of this admission, in a section entitled "Black march to death," Abu-Jamal sarcastically writes, "How true. McCleskey can't be correct, or else the whole system is incorrect. Now that couldn't be the case, could it?" (78). Yet instead of facing the accusation of wide spread misconduct head on, the court's opinion seems to spend most of its explanation deflecting the evidence along with their responsibility on this issue. The opinion argues, for example, that the "defendant must prove that the purposeful discrimination 'had a discriminatory effect' on him...to prevail under the Equal Protection Clause" (Latzer 234). Even though the Baldus study analyzes capital cases in Georgia from 1973-1978, and even though McCleskey was a black man tried and convicted of killing a white man in the state of Georgia in 1978, the majority opinion still holds that the statistics are insufficient in showing that McCleskey's sentencing was influenced by these apparent racial biases. Furthermore, the court argues that "a defendant who alleges an equal protection violation has the burden of proving 'the existence of purposeful discrimination,"' something it claimed McCleskey failed to do (Latzer 234). In other words, racial discrimination is apparently allowed, just as long as it is not done purposefully. The opinion concludes with a final deflection of responsibility by claiming that "McCleskey's arguments are best presented to the legislative bodies. It is not the responsibility-or indeed even the right-of this Court to determine the appropriate punishment for particular crimes" (Latzer 240).

Along with its rejection of "the likelihood allegedly shown by the Baldus study as the constitutional measure of an unacceptable risk of racial prejudice influencing capital sentencing decisions" (Latzer 237), what the opinion of the court fails to acknowledge is a reality that both Abu-Jamal and the dissenting opinion of the court put forth and analyze unabashedly: that the prejudiced ripples flowing from our common history of racism are still being felt today. The court's opinion certainly acknowledges our history of racism, but it fails to link the past and present: "Although the history of racial discrimination in this country is undeniable," argues Justice Powell, "we cannot accept official actions taken long ago as evidence of current intent" (236). This black-and-white form of reasoning is one that Abu-Jamal refuses to accept. Instead, he refers to Justice William Brennan's dissent in the case, which points out that "Georgia's legacy of a race-conscious criminal justice system, as well as this Court's own recognition of the persistent danger that racial attitudes may affect criminal proceedings, indicates that McCleskey's claim is not a fanciful product of mere statistical artifice" (Latzer 244). In fact, Abu-Jamal imbeds Brennan's language within his own rejection of the court's opinion when he writes, "McCleskey's claim, based on sophisticated statistical and multiple regression analyses, buttressed by our understanding of history and human experience,' was not disproved by the McCleskey Court; rather, it was rejected out of fear" (12-13).

Another voice Abu-Jamal integrates within his own writing to exhibit the importance of drawing upon our common past as a way of understanding the present is that of Delbert Tibbs-a onetime death-row inmate who was able to obtain an appellate reversal. Of the McCleskey decision, Tibbs writes, "That Justice was speaking as if there were no Civil War and no chattel slavery. He spoke as if there were no history of lynchings, as if there were no Dred Scott decision, no Medgar Evers, Little Rock, nor 'Bombingham.' Memphis didn't happen in that America" (qtd. in Abu-Jamal 14). "What does happen, in this America," Abu-Jamal asserts, "is the cheapening of black life and the placing of a premium on white life" (14). To understand fully the power and the importance of this implication in the present, Abu-Jamal implies, we must understand the perceptions of the time of Dred Scot and beyond. Because just as the life of an African American was found essentially to be worth much less than that of a white man in Dred Scott, as the Baldus study suggests and Abu-Jamal explicitly asserts, black life is still perceived as being cheaper than white life. This simultaneously historic and contemporary perception of current injustices, however, is not solely limited to those most severely influenced by them. Rather, in the words of Justice Brennan:

"It is tempting to pretend that minorities on death row share a fate in no way connected to our own, that our treatment of them sounds no echoes beyond the chambers in which they die. Such an illusion is ultimately corrosive, for the reverberations of injustice are not so easily confined ..." (qtd. in Abu-Jamal 15). 
By juxtaposing the language of Brennan, Tibbs, and others alongside his own is first a structural decision that mirrors nicely Abu-Jamal's claims regarding the connectivity between those living both within and beyond the confines of prison. In doing so, he also reveals the importance of obtaining a historical perspective, not solely so that we can draw lines of connection between the past and present, but so that we can learn to draw them between each other: between black and white, rich and poor, CEO and the laborer, and ultimately between imprisoned and "free." Furthermore, in the shared view of Abu-Jamal, Tibbs, and Brennan, regardless if one accepts the humanity of death-row inmates and views them as "common sinners," their fates are still connected to our own. Therefore, even if one refuses what I have claimed is the essential premise of Abu-Jamal's writing-that prisoners are not "moral aliens" but "common sinners" and products of the same history and humanity that is shared by all-Live From Death Row works on a second level: one that objectively reveals the multiple ways those living beyond the walls of prison are directly influenced by those living within them.

\section{Waste Camps, Money, and Toxic Water}

Without leaning as heavily upon arguments regarding our shared history of racism, another way that Live From Death Row exhibits the existing connection between the "free" and the imprisoned is in its critiques of our prison systems, what Abu-Jamal calls "Human waste camps... where humans are transformed into nonpersons, numbered beings cribbed into boxes of unlife, where the very soul is under destructive onslaught" (73). One way Abu-Jamal contends that US prisons are often a place "where humans are transformed into nonpersons" is in his description of the mandatory strip searches that are required before non-contact visits, a process that causes these visits to become "an exercise in humiliation" (8). In Pennsylvania and in many other "death states," Abu-Jamal writes, "non-contact visits are the rule. It is not just a security rule; it is a policy and structure that attempts to sever emotional connection by denying physical connection between the visitor and the inmate" (8). Yet even though these visits allow for zero contact by placing a Plexiglas barrier between the inmate and the visitor, mandatory strip searches are still carried out immediately before and after the visits. Abu-Jamal describes the cold, prison guard rhetoric involved in such searches: "Open yer mouth. Stick out your tongue. You wear any dentures? Lemme see both sides of your hands. Pull your foreskin back. Lift your sac. Turn around. Bend over. Spread your cheeks. Bottom of yer feet. Get dressed." (9)

The obvious question that arises regarding this practice is simple: What is the point of strip searches in non-contact visits? Abu-Jamal proposes that such searches have nothing to do with security issues but that due to these searches as well as the non-contact visits, "prisoners become as isolated psychologically as they are temporally and spatially ... they become 'dead' to those who know and love them, and therefore dead to themselves" (10). In this soul-killing process, death-row inmates are slowly stripped of their humanity and are essentially put to death twice. These psychological torments, along with having to spend twenty-two hours of everyday in an isolated cell, Abu-Jamal asserts, helps to create the previously discussed "Harry Washingtons by the score" (25), men who, because of the psychological pains of prison life, have slowly drifted from sanity.

Readers who do not share the "common sinner" viewpoint of this essay may not only fail to be moved by Abu-Jamal's evocation of the horrors of prison life, they may also question how the brutalities faced by prisoners have any clear connection to their own lives. Of course, Abu-Jamal does not fail to provide an explanation to this skepticism, because in a section entitled, "Actin' like life's a ball game," he discusses the "three strikes, you're out" metaphor-a politically-driven policy that calls for additional penalties on the third felony of a criminal. Of the get-tough-on-crime jingles that often sprout in abundance during election seasons, Abu-Jamal remarks, "When I hear easy, catchy, mindless slogans like 'three strikes, you're out,' I think of men like Rabbani" (43).

Rabbani is the name Abu-Jamal gives to a young man he met in prison who, as a 15 year-old, "was convicted of all charges and sentenced to fifteen to thirty years in prison, for an alleged robbery with a $\mathrm{CO}_{2}$ air pistol" (42). Abu-Jamal uses Rabbani's story to argue that the current conditions of prison life are a far cry from the centers of rehabilitation that they are supposed to embody. In fact, as Abu-Jamal notes in "A bill that is a crime," in the political rhetoric of getting tough on a crime, legislation was passed that states, "No basic grant shall be awarded under the subpart to any individual who is incarcerated in any federal or state penal institution" (110): a bill which implies that ignorance somehow "fights crime or protects society ..." (110). In yet another section, Abu-Jamal refers to this same piece of legislation only to claim, "This is the face of 'correction,' which outlaws education among those who have an estimated 60 percent illiteracy rate" (54). To return to Rabbani, because of such legislation and the negative perceptions aimed against prisoners, "Like tens of thousands of his generation, his time in hell equipped him with no skills of value 
to either himself or his community" (42). Instead, Rabbani, who "grew into manhood in shackles, and every time I saw him he seemed bigger in size but more bitter in spirit" (42), returns to his community in worse condition than when he left it. So even the readers who deny the shared humanity that radiates between Rabbani and themselves will not be able to deny the likelihood that-due to our ' 'corrections' ... where none are corrected"-they will eventually feel the impact of one of the Rabbanis of the world, either economically, legally, or perhaps even physically. And even if they could somehow avoid this impact, as Abu-Jamal asks, "Who profits (other than the prison establishment itself) from stupid prisoners?" (54).

This issue of profit does not stop at the level of rehabilitation however, because perhaps the most evident way that Abu-Jamal shows how those living outside the walls of prison are objectively connected to those within is by following a different political slogan, one used by former president Clinton in his first presidential campaign: "It's the economy, stupid." In a section entitled "Already out of the game," Abu-Jamal once again attacks what he calls "the 'three strikes, you're out' rage" by claiming that this "newest political fever sweeping the nation" will only open "the door to a state-by-state march to an unprecedented prison building boom" (106). Not only does he argue that the "three strikes, you're out" initiative will not help to deter crime, he notes the outrageous costs American's must account for in funding the growing prison systems of a country that, as of Live From Death Row's publication in 1996, already led the world in the percentage of its citizens living behind bars. Speaking of the high costs of this undertaking, Abu-Jamal writes, "Pennsylvanians are paying over $\$ 600$ million this fiscal year for their prisons; Californians, over $\$ 2.7$ billion this year, with costs for next year expected to top costs for higher education" (107). In this way, Abu-Jamal implicitly asks those who will not consider death-row inmates as human beings to at least consider their own pocketbooks. Because even those who will not accept the shared humanity hypothesis presented within Live From Death Row need look no farther than their bank accounts to accept the shared economy reality.

Although the vignettes in Live From Death Row reveal connections between prisoners and non-prisoners on two levels-the second of which, as presented here, reveals this obvious connection even to those who do not follow what I have described as Abu-Jamal's "common sinner" approach-the true essence of his writing makes no concessions with regard to the humanity of the incarcerated. And the very human connection between those both beyond and behind prison bars is most clearly exhibited in the section "A Toxic Shock." In this section, Abu-Jamal and his fellow inmates learn that "an oil based substance has washed its way into institutional springs, due to heavy rains" (51). For this reason, the prisoners are advised to neither bathe in nor drink the water. Of this experience, Abu-Jamal's words are reminiscent of those of John Donne's in "Meditation 17," where "No man is an island, entire of itself; every man is a piece of the continent, a part of the main..." Abu-Jamal writes:

The heavy gaseous odor still lingers, and a dark oily ring stains cups. It makes me wonder about a saying my wife and I share, that bars and steel can't stop the power of love. The dark side of that also is true: bars, steel, and court orders can't stop the seepage of pollution that afflicts both the caged and the "free." Despite the legal illusions erected by the system to divide and separate life, we the caged share air, water, and hope with you, the not-yet-caged. We share your same breath. As John Africa teaches, "All life is connected" (51-52).

Here, Abu-Jamal most explicitly puts forth his argument for viewing the prisoner as "common sinner," as men and women who are intricately connected to the rest of society. Abu-Jamal transforms this real, isolated event into metaphorical prose that views all life, even the lives of those behind bars, as being connected not only by the uplifting aspects of humanity but by its disheartening realities as well. Not only do we share in a common history and humanity; not only are we connected and implicated by the baser characteristics of our corrections systems that fail to correct; and not only is that same system rapidly growing and therefore contributing to the depletion of our shared economy; on a level that is both spiritual and physical, we are also connected by our very existence on this earth, sharing both polluted water and the "same breath." Just as Abu-Jamal's writing implicitly argues that we are linked by our shared history of racism, the assorted vignettes within Live From Death Row are all conjoined by a common plea for humanity-not solely on behalf of prisoners but for society at large. Because as Fyodor Dostoyevsky reminds us and as Abu-Jamal echoes throughout Live From Death Row, "The degree of civilization in a society can be judged by entering the prisons" (qtd. in Abu-Jamal 62).

\section{Competing Interests}

The author has no competing interests to declare. 


\section{References}

Abu-Jamal, Mumia. "Declaration of Mumia Abu-Jamal." Free Mumia. www.freemumia.com/declaration-ofmumia-abu-jamal/. 26 Jan. 2018.

Abu-Jamal, Mumia. Live From Death Row. New York: Avon Books, 1996.

Banner, Stuart. The Death Penalty. Cambridge: Harvard University Press, 2002.

Cohen, Daniel A. Pillars of Salt, Monuments of Grace: New England Crime Literature and the Origins of American Popular Culture 1674-1860. Amherst: University of Massachusetts Press, 2006.

Conniff, Brain. "Mumia Abu-Jamal's Live From Death Row as Post-Legal Prison Writing." Rodopi Perspectives on Modern Literature, no. 30, 2005, pp. 159-172.

Davis, Angela Y. Are Prisons Obsolete? New York: Seven Stories Press, 2003.

Eliot, T. S. "Tradition and the Individual Talent." The Critical Tradition. Ed. David H. Richter. $3^{\text {rd }}$ ed. Bedford/St. Martin's, 2007, pp. 537-541.

Foucault, Michel. Discipline \& Punish: The Birth of the Prison. Trans. Alan Sheridan. New York: Vintage Books, 1995.

Glaze, Lauren E., and Danielle Kaeble. "Correctional Populations in the United States, 2013." Bureau of Justice Statistics. www.bjs.gov/index.cfm?ty=pbdetail\&iid=5177. 20 Jan. 2018.

Halttunen, Karen. Murder Most Foul: The Killer and the American Gothic Imagination. Cambridge: Harvard University Press, 1998.

Latzer, Barry Ed. "Race Discrimination and Capital Punishment-McCleskey v. Kemp (1987)." Death Penalty Cases: Leading U.S. Supreme Court Cases on Capital Punishment. Massachusetts: Butterworth-Heinemann, 1998, pp. 231-250.

The World Prison Brief. www.prisonstudies.org/. 20 Jan. 2018.

Wideman, John Edgar. Introduction. Live From Death Row. By Mumia Abu-Jamal. New York: Avon Books, 1996.

How to cite this article: Moats, B 2019 Lives From Death Row: Common Sinners and Current Pasts. Anthurium 15(2): 9, 1-9. DOl: https://doi.org/10.33596/anth.383

Published: 23 September 2019

Copyright: (c) 2019 The Author(s). This is an open-access article distributed under the terms of the Creative Commons Attribution 4.0 International License (CC-BY 4.0), which permits unrestricted use, distribution, and reproduction in any medium, provided the original author and source are credited. See http://creativecommons.org/licenses/by/4.0/. 